\title{
CSATÓ LÁSZLÓ
}

\section{Pontozási rendszerek szimulációs összehasonlítása}

Egyéni preferencialisták aggregálásának elterjedt eszköze a pontozási rendszerek használata, amikor az egyes rangsorok minden pozíciója adott számú pontot ér, az aggregált sorrend pedig az alternatívák így összegyüjtött pontjai alapján alakul ki. Általában ezt az eljárást alkalmazzák több egymást követő versenyből álló sportbajnokságok eredményének meghatározására. Tanulmányunk ebben az összefüggésben vizsgálja a következő két, egyaránt elkerülendő esemény közötti átváltást: 1 . a bajnoki cím korai megszerzése, már a sorozat utolsó néhány futama előtt ismertté válik a győztes kiléte; 2 . a bajnok egyetlen versenyt sem nyer meg. Szimulációs megközelítés segítségével számszerúsítjük e kockázatokat a legrangosabb nemzetközi autóverseny, a Forma-1 négy történelmi pontozási rendszere esetében. Mindegyik versenyképesnek bizonyul a társadalmi választások elmélete által ajánlott, kedvező axiomatikus tulajdonsággal rendelkező mértani pontozással szemben. A jelenleg használt szabály észszerü kompromisszumnak tünik a két veszély mérséklésére. Eredményeink hasznos adalékokkal szolgálnak a Forma-1 pontozási rendszereinek fejlődéséhez, és új szempontokkal gazdagítják az egyes pozíciókért járó pontok megválasztásának irodalmát.* Journal of Economic Literature (JEL) kód: C44, C63, Z20.

\footnotetext{
„Senki sem szolgálhat két úrnak. Mert vagy az egyiket gyülöli és a másikat szereti; vagy egyikhez ragaszkodik, és a másikat megveti. Nem szolgálhattok Istennek és a Mammonnak." (Máté evangéliuma, 6:24)
}

\footnotetext{
* A kutatást az MTA Prémium Posztdoktori Kutatói Program PPD2019-9/2019 pályázata támogatta. Hálás vagyok Alexei Y. Kondratevnak és Josep Freixasnak az inspirációért, Alexei Y. Kondratev, Petróczy Dóra Gréta és egy anonim bíráló hasznos tanácsaiért, valamint Petróczy Dóra Gréta és Tóvári Gergő segítségéért az adatbázis összeállításában. A szimulációs program elkészítése lehetetlennek bizonyult volna a szerző édesapja, Csató László közreműködése nélkül.
}

Csató László, ELKH SZTAKI Mérnöki és Üzleti Intelligencia Kutatólaboratórium Operációkutatás és Döntési Rendszerek Kutatócsoport, BCE Operációkutatás és Aktuáriustudományok Tanszék (e-mail: laszlo.csato@uni-corvinus.hu).

A kézirat első változata 2021. január 19-én érkezett szerkesztőségünkbe.

DOI: http://dx.doi.org/10.18414/KSZ.2021.7-8.847 


\section{Bevezetés}

Számos sportbajnokság versenyek sorozatából áll. Minden versenyen az egyes helyezések adott számú pontot érnek, a versenyzök pontjait a szezon végén összeadják, és a legtöbb pontot elérő lesz a bajnok. Ezt az aggregációs eljárást pontozási rendszernek nevezzük, ilyeneket használnak többek között a motorsportban (például Forma-1), kerékpárversenyeken (például a Tour de France pontversenye) vagy különböző téli sportokban (például biatlon-világkupa). A pontozási rendszer kiválasztása a sportbajnokságok tervezésének fontos eleme (Csató [2021c]).

A társadalmi választások elméletének nevezetes eredményei szerint a pontozási rendszerek használata az egyéni preferenciák aggregálásában szintén megkerülhetetlen (Smith [1973], Young [1975]). Ezért e rendszerek vizsgálata messze nem csak sportgazdaságtani jelentőségű: más területeken - a döntéselméletben, a játékelméletben, a gépi tanulásban, a piactervezésben vagy a politikaelméletben - szintén hasznos lehet. Az irodalomban több axiomatikus karakterizáció született (Nitzan-Rubinstein [1981], Chebotarev-Shamis [1998], Merlin [2003], Llamazares-Peña [2015], Kondratev és szerzötársai [2019]), és léteznek javaslatok az egyes pozíciókért járó pontok megválasztására is (Stein és szerzőtársai [1994], Llamazares-Peña [2015]). Úgy véljük, bármilyen, az egyes pontozási rendszerek következményeit feltáró kutatás igényt tarthat az ezeket alkalmazó gazdasági döntéshozók figyelmére.

Kiindulópontunk két, egyaránt elkerülendő jelenség közötti átváltás, amelyeket a sportból vett történelmi példák illusztrálnak.

\section{1. példa (bajnoki cím korai megszerzése)}

A 2002-es Forma-1-es világbajnokság pontozási rendszerét az 1. táblázat, az öt legjobb versenyző 17 futamon elért helyezéseit a 2. táblázat tartalmazza. Michael Schumacher az első 11 versenyen 96 pontot szerzett, az ekkor második Juan Pablo Montoya azonban csupán 34-et. Schumacher 62 pontos előnye birtokában már 11 futamot követően megszerezte a világbajnoki címet, hiszen a hátralevő hat versenyen legfeljebb 60 pontot lehetett gyüjteni.

\section{1. táblázat}

A 2002-es Forma-1-es világbajnokság pontozási rendszere

\begin{tabular}{lc}
\hline Helyezés & Pontszám \\
\hline 1. & 10 \\
2. & 6 \\
3. & 4 \\
4. & 3 \\
5. & 2 \\
6. & 1 \\
\hline
\end{tabular}




\section{2. táblázat}

A 2002-es Forma-1-es világbajnokság eredménye (helyezések)

\begin{tabular}{|c|c|c|c|c|c|}
\hline \multirow[t]{2}{*}{ Futam } & \multicolumn{5}{|c|}{ Versenyző } \\
\hline & Schumacher, M. & Barrichello & Montoya & Schumacher, R. & Coulthard \\
\hline 1. & 1 & - & 2 & - & - \\
\hline 2. & 3 & - & 2 & 1 & - \\
\hline 3. & 1 & - & 5 & 2 & 3 \\
\hline 4. & 1 & 2 & 4 & 3 & 6 \\
\hline 5. & 1 & - & 2 & 11 & 3 \\
\hline 6. & 1 & 2 & 3 & 4 & 6 \\
\hline 7. & 2 & 7 & - & 3 & 1 \\
\hline 8. & 1 & 3 & - & 7 & 2 \\
\hline 9. & 2 & 1 & - & 4 & - \\
\hline 10. & 1 & 2 & 3 & 8 & 10 \\
\hline 11. & 1 & - & 4 & 5 & 3 \\
\hline 12. & 1 & 4 & 2 & 3 & 5 \\
\hline 13. & 2 & 1 & 11 & 3 & 5 \\
\hline 14. & 1 & 2 & 3 & 5 & 4 \\
\hline 15. & 2 & 1 & - & - & 7 \\
\hline 16. & 2 & 1 & 4 & 16 & 3 \\
\hline 17. & 1 & 2 & 4 & 11 & - \\
\hline Összpontszám & 144 & 77 & 50 & 42 & 41 \\
\hline
\end{tabular}

A fenti eset egy, a legtöbb érintett számára minden bizonnyal kedvezőtlen forgatókönyvet mutat be. A szabályalkotó Nemzetközi Automobil Szövetség (Fédération Internationale de l'Automobile, FIA) például aligha örül annak, ha ilyen hamar eldől a győztes kiléte, mivel erősen csökkentheti a fennmaradó futamok iránti érdeklődést.

\section{2. példa (bajnoki cím futamgyözelem nélkül)}

A 16 futamból álló, 1999-es gyorsaságimotoros-világbajnokság (MotoGP) pontozási rendszerét a 3. táblázat, a 125 köbcentiméteres kategória ${ }^{1}$ első hét versenyzőjének helyezéseit a 4. táblázat tartalmazza. Emilio Alzamora úgy szerezte meg a világbajnoki címet, hogy az egész szezonban egyetlen versenyt sem nyert meg. Eközben a második és harmadik helyezett egyaránt öt-öt futamon győzött, és hat versenyző legalább egy pályán elérte az első pozíciót.

\footnotetext{
${ }^{1}$ A világbajnokságon három kategória volt, lásd https://hu.wikipedia.org/wiki/1999-es_MotoGP-
} vil\%C3\%A1gbajnoks\%C3\%A1g. 


\section{3. táblázat}

Az 1999-es MotoGP-világbajnokság (125 köbcentiméter) pontozási rendszere

\begin{tabular}{lc}
\hline Helyezés & Pontszám \\
\hline 1. & 25 \\
2. & 20 \\
3. & 16 \\
4. & 13 \\
5. & 11 \\
6. & 10 \\
7. & 9 \\
8. & 8 \\
\hline
\end{tabular}

\begin{tabular}{cc}
\hline Helyezés & Pontszám \\
\hline 9. & 7 \\
10. & 6 \\
11. & 5 \\
12. & 4 \\
13. & 3 \\
14. & 2 \\
15. & 1 \\
\hline
\end{tabular}

\section{4. táblázat}

Az 1999-es MotoGP-világbajnokság (125 köbcentiméter) eredménye (helyezések)

\begin{tabular}{|c|c|c|c|c|c|c|c|}
\hline \multirow[t]{2}{*}{ Futam } & \multicolumn{7}{|c|}{ Versenyző } \\
\hline & Alzamora & Melandri & Azuma & Locatelli & Ueda & Scalvini & Vincent \\
\hline 1. & 2 & - & 1 & 18 & - & 3 & 4 \\
\hline 2. & 3 & - & 1 & - & - & 12 & - \\
\hline 3. & 3 & - & 1 & 5 & 8 & 4 & 10 \\
\hline 4. & 3 & 6 & 4 & 1 & 5 & 7 & 2 \\
\hline 5. & 6 & 2 & 7 & 1 & 3 & - & 5 \\
\hline 6. & 2 & 3 & - & 6 & 4 & 10 & 1 \\
\hline 7. & 4 & 8 & 1 & 3 & 2 & 5 & 7 \\
\hline 8. & 3 & 5 & 1 & 4 & 2 & 6 & 9 \\
\hline 9. & 2 & 1 & 6 & 4 & 5 & 7 & 10 \\
\hline 10. & 6 & 1 & 12 & - & 2 & 4 & 10 \\
\hline 11. & 4 & 1 & 10 & 11 & 5 & 19 & 3 \\
\hline 12. & 2 & - & - & 8 & 3 & 1 & 4 \\
\hline 13. & 15 & 1 & 5 & 6 & - & 4 & - \\
\hline 14. & - & 3 & 14 & 4 & - & 1 & 2 \\
\hline 15. & 3 & 2 & 6 & 8 & 1 & - & 13 \\
\hline 16. & 2 & 1 & - & 3 & - & 7 & - \\
\hline Összpontszám & 227 & 226 & 190 & 173 & 171 & 163 & 155 \\
\hline
\end{tabular}

Ez a példa egy másik nemkívánatos helyzetet vázol. A sportversenyek nézői azt szeretik, amikor az aktuális verseny második helyezettje mindent megtesz a győzelemért, nem kerüli a kockázatos előzéseket. 
Ugyanakkor a szervezők e furcsa szezon után sem módosították a szabályokat, a gyorsaságimotoros-világbajnokságon 1993 óta a 3. táblázatban közölt pontozási rendszert alkalmazzák. Ezzel szemben a Forma-1 autóversenyen az 1. példát követő évben, 2003-ban módosítottak a pontszámok kiosztásán, az első hat helyett nyolc pozícióért járt rendre 10, 8, 6, 4, 3, 2, 1 pont. Ebben a rendszerben a 2002es eredmények alapján az első 11 futamon Michael Schumacher 102, az őt követő Montoya 50 pontot gyüjtött volna. Így a világbajnoki cím sorsa valamivel később, csak 12 futam után dőlt volna el.

A 2002-es pontozási rendszerhez képest a 2003-as szabály egyetlen versenyzőnek sem ad kevesebb pontot, de az első kivételével bizonyos helyezésekért több pont jár. Ezért a reform csökkentette annak valószínűségét, hogy korán eldöl a bajnoki cím sorsa - viszont ezzel egyidejüleg fokozta a futamgyőzelem nélküli nyerés veszélyét. Tehát létezik egyfajta átváltás az egyes versenyek és az egész sorozat izgalmassága között, az egyik többnyire csak a másik rovására növelhető, ami részben magyarázatul szolgálhat a Forma-1 pontozási rendszerének gyakori változtatására (Corvalan [2018], Haigh [2009], Kondratev és szerzötársai [2019]).

A következőkben e probléma jobb megértéséhez szeretnénk hozzájárulni egy szimulációs megközelítés alkalmazásával. Ennek során a Forma-1 autóverseny historikus futamainak alapján fiktív szezonokat generálunk, majd számszerűsítjük, hogy különbözö pontozási rendszerek mellett milyen eséllyel következhetett volna be a két kedvezőtlen forgatókönyv (a bajnoki cím korai, illetve futamgyőzelem nélküli megszerzése). Ezután az adatbázist és a módszertant ismertetjük. Az eredmények tárgyalása után a tanulmányt rövid összegzéssel fejezzük be.

\section{A szimuláció}

A két kockázat értékeléséhez hipotetikus, a képzeletbeli futamok eredményeit tükröző rangsorokra van szükségünk. Ehhez a Forma-1-es autóverseny 2007 és 2019 közötti szezonjaiból indulunk ki, amelyek föbb jellemzőit az 5. táblázat foglalja össze. Az adattisztítást Csató [2021a] részletezi.

$\mathrm{Az}$ adatbázisban a versenyzőket a szezon végén elért helyezésük sorszámával azonosítjuk. Minden futam eredménye egy $k$-elemü permutáció, ahol $k$ az adott évben számításba vett versenyzők száma (lásd az 5. táblázatot). Például a [2., 3., 1.] vektor egy olyan futamnak felel meg, ahol a későbbi világbajnok második, a világbajnokság második helyezettje harmadik lett, míg a versenyt az összesítésben harmadik pozíciót elérő versenyző nyerte.

Egy szezon minden futamának eredményét a következő két eljárás valamelyikével generáljuk:

- M1. MÓDSZER: az adatbázisban szereplö évek összes futamából visszatevéses mintát veszünk.

- M2. MÓDSzER: az adatbázisban szereplő évek összes futamából visszatevéssel kiválasztunk kettőt. Minden versenyző ideiglenes helyezését a két kisorsolt futam valamelyikéből, egymástól függetlenül határozzuk meg. Mivel ezek az ideiglenes 
5. táblázat

Az adatbázisban szereplő Forma-1-es szezonok jellemzői

\begin{tabular}{lcccc}
\hline Év & A futamok száma & A versenyzők száma & A cím megszerzése & Pontelőny \\
\hline 2007 & 17 & 20 & 17 & 1 \\
2008 & 18 & 19 & 18 & 1 \\
2009 & 17 & 20 & 16 & 11 \\
2010 & 19 & 18 & 19 & 4 \\
2011 & 19 & 18 & 15 & 122 \\
2012 & 20 & 18 & 20 & 3 \\
2013 & 19 & 18 & 16 & 155 \\
2014 & 19 & 17 & 19 & 67 \\
2015 & 19 & 18 & 16 & 59 \\
2016 & 21 & 19 & 21 & 5 \\
2017 & 20 & 19 & 18 & 46 \\
2018 & 21 & 20 & 19 & 88 \\
2019 & 21 & 19 & 19 & 87 \\
\hline
\end{tabular}

A versenyzők száma: azon pilóták száma, akik legalább egy versenyen az első 10 pozíció valamelyikén végeztek.

A cím megszerzése: hány futam után dőlt el a világbajnoki cím sorsa.

Pontelőny: az első és a második helyezett pontszámának különbsége a szezon végén.

Megjegyzés: 2014-ben az utolsó, abu-dzabi nagydíjon dupla pontokat osztottak ki, így a győztes 50 pontot kapott. Ez magyarázza a nagy pontelönyt, miközben a bajnoki cím sorsa csak az utolsó futamon dőlt el.

helyezések ritkán adnak megfelelő rangsort, a versenyzőket ideiglenes helyezéseik szerint sorba rendezzük, az esetleges holtversenyeket pedig véletlenszerüen döntjük el.

Az M1. módszer mögötti feltevés kézenfekvő, minden valós futamra egy lehetséges forgatókönyvként tekintünk. Ugyanakkor egy historikus futam eredménye csupán számtalan sztochasztikus változó egyetlen realizációja, vagyis a ténylegesen megfigyelt sorrendek nem feltétlenül tükröznek minden észszerü lehetőséget. Például, ha egy versenyző minden futamon első vagy harmadik lett, akkor az M1. módszer használatakor egyetlen véletlenül generált esetben sem lehet második, jóllehet ez reális világállapotnak tünik. Ez indokolja az M2. módszer használatát, a mely két valós futam eredményét kombinálja. Ennek során a genetikus algoritmusok irodalmából ismert egyenletes keresztezés (uniform crossover) elvét követjük: a két verseny eredményét reprezentáló vektorok adott pozíciójú elemei közül az egyik véletlenszerüen választott adja a megfelelő versenyző ideiglenes helyezését. Végül ezeket az ideiglenes helyezéseket „sorba rendezve” kapjuk egy „szintetikus” futam eredményét. 


\section{3. példa (futamgeneráló módszerek)}

Tegyük fel, hogy az adatbázisban mindössze három versenyző és két futam, $A=[1 ., 3 ., 2$.$] és B=[2 ., 1 ., 3$.$] szerepel. Az M1. módszer 50$ százalékos valószínűséggel az $A, 50$ százalékos valószínűséggel a $B$ futam eredményét adja. Az M2. módszer használatakor (a három versenyző miatt) $2^{3}=8$ lehetséges ideiglenes rangsor keletkezhet, mindegyik 1/8 eséllyel fordul elö. Ezeket és a megfelelő futameredményeket a 6. táblázat tartalmazza. Az egyes rangsorok előfordulásának valószínűségeit a 7. táblázat összegzi. Bár az eredeti adatbázisban a harmadik versenyző egyszer sem végzett másodikként, az M2. módszer alkalmazásakor ez 25 százalékos eséllyel megtörténhet.

\section{6. táblázat}

Lehetséges forgatókönyvek a 3. példában az M2. módszer használatával

\begin{tabular}{lrr}
\hline Ideiglenes helyezések & \multicolumn{2}{c}{ A futam lehetséges eredményei } \\
\hline$[1 ., 3 ., 2]$. & \multicolumn{2}{c}{$[1 ., 3 ., 2]}$. \\
{$[1 ., 3 ., 3]$.} & {$[1 ., 2 ., 3]$.} & {$[1 ., 3 ., 2]$.} \\
{$[1 ., 1 ., 2]$.} & {$[1 ., 2 ., 3]$.} & {$[2 ., 1 ., 3]$.} \\
{$[2 ., 3 ., 2]$.} & {$[1 ., 3 ., 2]$.} & {$[2 ., 3 ., 1]$.} \\
{$[1 ., 1 ., 3]$.} & {$[1 ., 2 ., 3]$.} & {$[2 ., 1 ., 3]$.} \\
{$[2 ., 3 ., 3]$.} & {$[1 ., 2 ., 3]$.} & {$[1 ., 3 ., 2]$.} \\
{$[2 ., 1 ., 2]$.} & {$[2 ., 1 ., 3]$.} & {$[3 ., 1 ., 2]$.} \\
{$[2 ., 1 ., 3]$.} & & {$[2 ., 1 ., 3]$.} \\
\hline
\end{tabular}

\section{7. táblázat}

Egy futam lehetséges eredményei a 3. példában az M2. módszer használatával

\begin{tabular}{lc}
\hline A futam eredménye & Valószínüség \\
\hline$[1 ., 2 ., 3]$. & $1 / 16+1 / 16+1 / 16+1 / 16=4 / 16=1 / 4$ \\
{$[1 ., 3 ., 2]$.} & $1 / 8+1 / 16+1 / 16+1 / 16=5 / 16$ \\
{$[2 ., 1 ., 3]$.} & $1 / 16+1 / 16+1 / 16+1 / 8=5 / 16$ \\
{$[2 ., 3 ., 1]$.} & $1 / 16$ \\
{$[3 ., 1 ., 2]$.} & $1 / 16$ \\
{$[3 ., 2 ., 1]$.} & 0 \\
\hline
\end{tabular}

Adott számú futamból álló szezon minden versenyének sorrendjét egymástól függetlenül generáljuk a fenti két módszer valamelyike révén.

A versenyzőket az adott évben szerzett pontjaik száma alapján rangsorolják. A holtversenyeket lexikografikus elven oldják fel, a több első, több második stb. helyezés alapján. Ha még ez az eljárás sem vezet eredményre, a szervező tetszőleges módon választhat (FIA [2019] 7.2. paragrafus). Az egyszerüség kedvéért számítógépes 
programunk csak az első két kritériumot (első: magasabb pontszám, második: több futamgyőzelem) vizsgálja, a fennmaradó pontegyenlőségeket véletlenszerüen oldja fel. Noha a pontozási rendszerek mellett más, többnyire páros összehasonlításokon alapuló módszereket is javasoltak a futamok eredményeinek aggregálására (CsatóPetróczy [2021], Petróczy [2021]), ezekkel itt nem foglalkozunk.

Jelen munka az alábbi nyolc pontozási rendszert elemzi:

- S1. sZABÁLY: 2010 óta a Forma-1-es autóverseny hivatalos rangsorolási elve. 2014ben a szezon utolsó futamán elért pontokat duplázták, 2019-ben pedig a leggyorsabb körért is járt egy pont, amennyiben az ezt elérő versenyző az első tíz hely valamelyikén végzett. Ezt a két változtatást a szimulációnk nem tartalmazza.

- S2. SZABÁLY: a Forma-1-es autóverseny hivatalos rangsorolási elve 1991 és 2002 között.

- S3. sZABÁLY: a Forma-1-es autóverseny hivatalos rangsorolási elve 1961 és 1990 között. Bár ezekben az években csak a futamok egy részhalmazának (például 1980 és 1990 között a legjobb 11 verseny) eredménye számított, a szimuláció során minden futamot figyelembe veszünk, ahogy 1979 óta a konstruktőri pontversenyben teszik.

- S4. sZABÁLY: a Forma-1-es autóverseny hivatalos rangsorolási elve 2003 és 2009 között.

- G1-G4. sza вÁLY: Kondratev és szerzőtársai [2019] 2. tételének axiomatikus karakterizációja értelmében kizárólag az egyparaméteres mértani pontozási rendszer konzisztens az egyhangú győztes és az egyhangú vesztes eltávolítására, ahol a kiosztandó pontok

$0,1,1+p, 1+p+p^{2}, 1+p+p^{2}+p^{3}, \ldots$

Az első tíz pozíciót díjazzuk, vagyis a j-edik helyezés értéke $\mathrm{p}>1$ esetén $\left(p^{11-j}-1\right) /(p-1) \approx p^{11-j}$,

amennyiben $1 \leq \mathrm{j} \leq 10$, egyébként nulla. Vegyük észre, hogy a pontozási rendszer független a pontszámok eltolásától és pozitív konstanssal történő szorzásától.

A nyolc pontozási rendszert a 8. táblázat tartalmazza.

Négy különböző paraméterértéket vizsgálunk, melyek rendre 1 (G1.), 1,05 (G2.), 1,3 (G3.), 1,6 (G4.).

A futamok generáláshoz használt adatok tekintetében szintén két esetet különböztetünk meg:

- teljes adatbázis: a 2010 és 2019 közötti évek minden futama,

- kompetitív adatbázis: az összes futam a 2007-es, 2008-as, 2009-es, 2010-es, 2012es és 2016-os szezonból.

A teljes adatbázis tíz olyan közelmúltbeli évet tartalmaz, amelyekben a pontozási rendszer lényegében azonos volt, ezért feltehetően a versenyzők ösztönzői sem változtak. A kompetitív adatbázis olyan idényekből áll, amelyek végén szoros eredmény született, a pontverseny első és második helyezettje között minimális különbséggel, a világbajnoki cím sorsa csak az utolsó vagy az utolsó előtti futamon dőlt el (lásd az 5. táblázat utolsó két oszlopát). 
8. táblázat

Az elemzésben vizsgált pontozási szabályok

\begin{tabular}{lrrrrrrrc}
\hline Helyezés & \multicolumn{7}{c}{ Pontozási rendszer } \\
\cline { 2 - 8 } & $S 1$. & $S 2$. & $S 3$. & $S 4$. & $G 1$. & $G 2$. & $G 3$. & $G 4$. \\
\hline 1. & 25 & 10 & 9 & 10 & 10 & 12,58 & 42,62 & 181,59 \\
2. & 18 & 6 & 6 & 8 & 9 & 11,03 & 32,01 & 112,87 \\
3. & 15 & 4 & 4 & 6 & 8 & 9,55 & 23,86 & 69,92 \\
4. & 12 & 3 & 3 & 5 & 7 & 8,14 & 17,58 & 43,07 \\
5. & 10 & 2 & 2 & 4 & 6 & 6,80 & 12,76 & 26,30 \\
6. & 8 & 1 & 1 & 3 & 5 & 5,53 & 9,04 & 15,81 \\
7. & 6 & 0 & 0 & 2 & 4 & 4,310 & 6,187 & 9,256 \\
8. & 4 & 0 & 0 & 1 & 3 & 3,1525 & 3,99 & 5,16 \\
9. & 2 & 0 & 0 & 0 & 2 & 2,05 & 2,3 & 2,6 \\
10. & 1 & 0 & 0 & 0 & 1 & 1 & 1 & 1 \\
\hline
\end{tabular}

A számítások során azt tapasztaltuk, hogy elhanyagolható valószínűséggel adódik olyan helyzet, amikor a világbajnok egyetlen futamon sem gyöz. A továbbiakban ezt a változatot eredeti forgatókönyvnek nevezzük. Ennek kézenfekvő magyarázata a 2007 és 2019 között használt két rangsorolási elv (S1. és S4.) „meredeksége”, amely erősen díjazza a kockázatvállalást az első pozíció megszerzése érdekében. Ez a motiváció azonban lényegesen gyengül, ha a bajnoki cím korai megszerzésének elkerülése érdekében viszonylag „lapos” pontozási rendszert választunk. Ezért egy alternatív, kockázatkerülő forgatókönyvet alkalmaztunk a világbajnokság futamgyőzelem nélküli megnyerése jelentette fenyegetés számszerüsítésére: miután a szezon összes futamának eredményét meghatároztuk, az $S 1$. szabály szerint kiválasztott világbajnok minden egyes futamgyőzelmét második helyezésre változtattuk, azaz ezeken a versenyeken megcseréltük az első két pozíciót elérő versenyzőt.

\section{4. példa (kockázatkerülö forgatókönyv)}

Tegyük fel, hogy a kisorsolt szezon két futamból áll, $A=[1 ., 2$., 3.] és $B=[2 ., 3 ., 1$.$] .$ Mind a nyolc szabály értelmében az első versenyzö lesz a világbajnok egy első és egy második pozíciójának köszönhetően. A kockázatkerülő forgatókönyv az $A$ futamon megcseréli az első két helyezettet, hiszen azt megnyerte az $S 1$. szabály szerinti világbajnok, a $B$ futam eredményén viszont nem változtat. Tehát a módosított szezon két futama $A^{\prime}=[2 ., 1 ., 3$.$] és B^{\prime}=[2 ., 3 ., 1$.$] . Most az első versenyzö ugyan egy futamot$ sem nyer, de nem is maradhat világbajnok, mert egy első és egy harmadik helyezés mindegyik vizsgált szabály esetén legalább annyit ér, mint két második, a holtversenyt eldöntő kritérium pedig a több futamgyőzelem. 
A fenti heurisztika mohó módon igyekszik maximalizálni a futamgyőzelem nélküli nyerés valószínűségét, a világbajnoki címre legesélyesebb versenyző semmiféle kockázatot sem vállal a futamok megnyerése érdekében.

Összefoglalva, egy szimulációs futás a következő lépésekből áll.

1. A historikus adatbázis kiválasztása: teljes vagy kompetitív.

2. A futamgeneráló eljárás megadása: M1. vagy M2. módszer.

3. Az eredeti forgatókönyv kiszámítása: a szezon $n$ futamának egymástól független generálása.

4. A világbajnok azonosítása a 8. táblázatban felsorolt nyolc szabály szerint.

5. Ellenőrzés: a világbajnok nyert-e legalább egy futamon.

6. Az utolsó olyan futam $(m)$ meghatározása, ahol még nem dőlt el a világbajnoki cím sorsa, azaz a későbbi világbajnok és az aktuális (nem feltétlenül a végső!) második helyezett pontszámának különbsége kisebb, mint $(n-m)$ és az első helyért járó pontok számának szorzata, vagy a két szám egyenlő, de a későbbi világbajnok legfeljebb $(n-m)$-mel több futamgyőzelemmel rendelkezik az aktuális második helyezettnél.

7. A kockázatkerülő forgatókönyv kiszámítása a 3. lépésben meghatározott eredeti forgatókönyv módosításával.

8. A 4-6. pont megismétlése a 7. lépésben kapott kockázatkerülő forgatókönyv esetén.

A teljes szimuláció minden esetben 100 ezer egymástól független futást tartalmaz.

A futameredményeket reprezentáló rangsorok előállítása során számos egyszerüsítéssel éltünk. Ugyanakkor fontos hangsúlyozni, hogy szemben néhány statisztikai tanulmánnyal (Graves és szerzőtársai [2003], Henderson-Kirrane [2018]), nem törekedtünk a Forma-1 megfelelő előrejelzésére, az egyes versenyzők nyerési valószínüségeinek pontos meghatározására. A különböző pontozási rendszerek összehasonlítására lényegében bármilyen reális statisztikai módszer alkalmas lehet (Appleton [1995]). Mindazonáltal szimulációnk - amint az a sportbajnokságok formátumainak elemzésekor megszokott (Csató [2020a], [2020b], [2021b], Dobránszky-Sziklai [2020]) - elsősorban kvalitatív következtetésekkel szolgál, a számszerü értékek leginkább egymáshoz viszonyítva értékelhetők.

\section{Eredmények}

Egy futamot unalmasnak hívunk, ha a világbajnoki cím sorsa már korábban eldőlt. $\mathrm{Az}$ 1. ábra e versenyek átlagos számának függvényében mutatja annak valószínűségét, hogy a világbajnok a szimulált szezon 20 futamának egyikén sem győz a kockázatkerülö forgatókönyv mellett. Miután itt és a továbbiakban sem tapasztalunk érdemi eltérést az M1. és M2. módszerek között, csak az utóbbit vizsgáljuk.

A két cél szemmel láthatóan egymás rovására javítható, a világbajnoki cím futamgyőzelem nélküli megszerzésének esélye az unalmas futamok várható számának növekedése árán csökkenthető. A mértani pontozási rendszerek családja ugyan kedvező 
1. ábra

Átváltás a világbajnoki cím korai és futamgyőzelem nélküli megszerzése között

(20 futamos szezon)

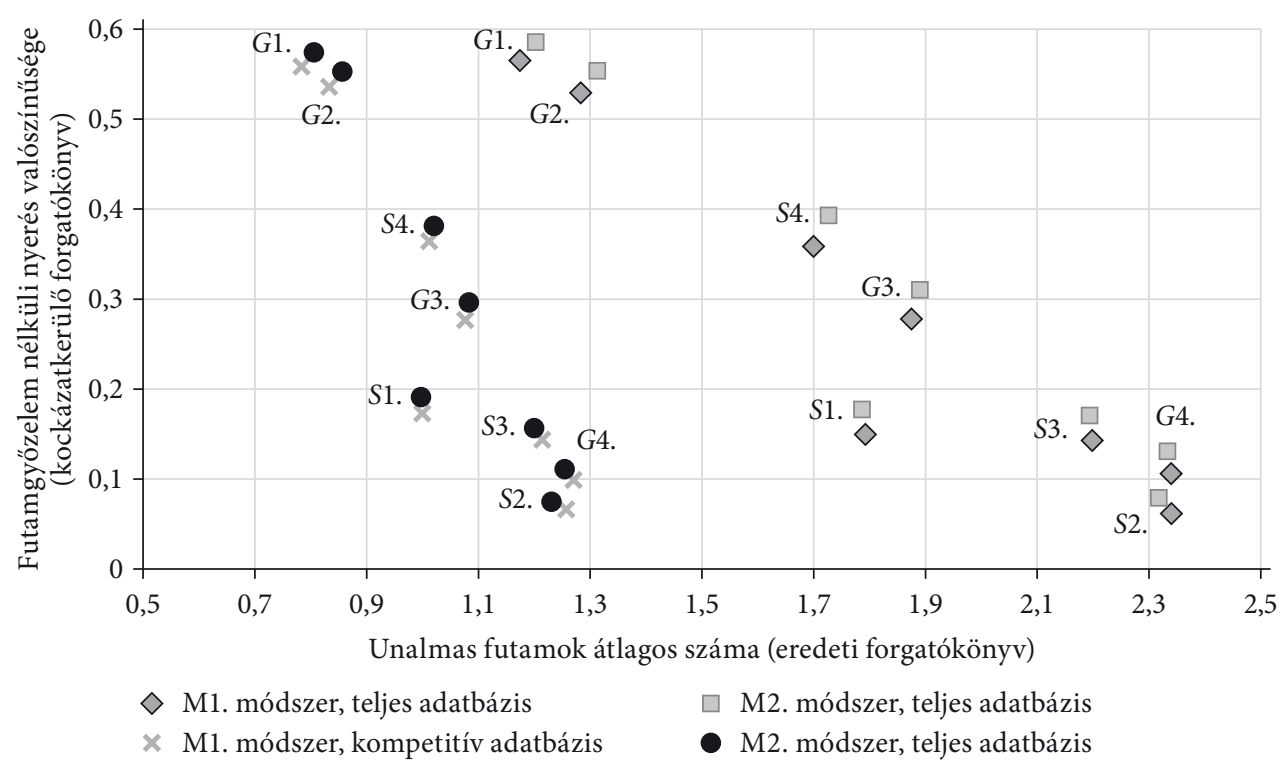

axiomatikus tulajdonságokkal rendelkezik (Kondratevés szerzötársai [2019]), a vizsgált mutatók tekintetében azonban nem jobb a ténylegesen használt szabályoknál: a G3. változat rosszabb az $S 1$. szabálynál, az $S 2$. pedig preferált a G4. szabállyal szemben. Az S2. és $S 3$. szabály alig különbözik, mindössze az első helyezett kap egy ponttal kevesebbet (8. táblázat), az apró eltérés mégis lényegesen befolyásolja mindkét mutató értékét: például az S3. szabály használata esetén az S2. szabályhoz képest csaknem megduplázódik a világbajnoki cím futamgyőzelem nélküli megszerzésének valószínűsége.

Érdemes felidézni a Forma-1 pontozási rendszereinek „evolúcióját”, amely az $S 3 . \rightarrow S 2 . \rightarrow S 4$. $\rightarrow$ S1. sorrendben alakult. Az $S 2$. $\rightarrow$ S4. váltást bizonyára az 1. példa inspirálta, Michael Schumacher 2002-ben a 17 futamos szezon 11 versenye után gyözött, az előző évben pedig a 17-ből 13 futamra volt szüksége ehhez. A világbajnoki cím korai megszerzése jelentette veszély csökkentésére a szervezők áttértek az S4. szabály alkalmazására, ez viszont túlzott reakciónak bizonyult, jelentősen csökkentette a futamgyőzelem relatív értékét. Ezért jelenleg a kompromisszumos $S 1$. rendszer érvényes, ami a világbajnoki cím futamgyőzelem nélküli megszerzése tekintetében mintegy félúton helyezkedik el a két korábbi szabály, S2. és S4. között, miközben elfogadható szinten tartja az unalmas versenyek várható értékét.

Az 1. ábra két további érdekes megfigyeléssel szolgál.

- A kompetitív adatbázis alapján az $S 1$. változat lényegében dominálja $S 4$.-et a szoros szezonokban (2007-2010, 2012, 2016), és éppen 2010-től tértek át S4.-ről S1.-re. Talán felismerték a döntéshozók, hogy a világbajnoki cím futamgyőzelem nélküli megszerzésének veszélye nagymértékben csökkenthető az unalmas futamok várható számának minimális emelkedése révén. 
- Az S1. pontozási rendszerhez képest $S 3$. alig csökkenti a futamgyőzelem nélküli nyerés esélyét, miközben lényegesen növeli az unalmas versenyek átlagos számát. Így aligha meglepő, miért nem tértek vissza a 2000-es években az S3. szabályhoz.

Mindent egybevetve, a szimulált adatsorokon a jelenleg használt $S 1$. pontozási rendszer viszonylag jól teljesít a két nemkívánatos fejlemény elkerülése szempontjából.

A 2. ábra, illetve a 3. ábra a világbajnoki cím korai megszerzése által jelentett fenyegetést számszerüsíti két mutató, a szezonvégi unalmas versenyek átlagos száma, illetve a 20-ból legalább három unalmas futam előfordulásának valószínüsége révén. Ez megerősíti a korábbi eredményeket, a $G 4$. mértani pontozás $(p=1,6)$ az $S 2$. és $S 3$. szabályhoz áll közel, míg a $G 3$. változat $(p=1,3)$ az $S 1$. és $S 4$. szabályok alternatíváját jelentheti, legalábbis e cél tekintetében. A világbajnoki cím eldöntése szempontjából érdektelen futamok aligha elkerülhetők, a jelenleg használt $S 1$. pontozás mellett mintegy 30 százalékos valószínüséggel legalább az utolsó három futam unalmas, és ennek esélye még akkor is 10 százalék körül marad, ha az erősen kompetitív szezonokból indulunk ki. Bár e nézettséget fenyegető veszély teljes mértékben sohasem küszöbölhető ki, a G1. vagy G2. mértani pontozás használatával nagyjából felére lenne csökkenthető az unalmas futamok várható száma - természetesen a világbajnoki cím futamgyőzelem nélküli megszerzése képviselte fenyegetés jelentős emelkedéséért cserébe. Ugyanakkor, mivel a sportág történetében eddig nem volt példa ilyesmire, megfontolandó lehet e szabályok kipróbálása.

Végül 4. ábra, valamint az 5. ábra a két bemutatott veszély alakulását vázolja a szezon hossza, azaz futamainak száma függvényében. Az unalmas versenyek várható száma lényegében lineárisan követi a futamok számát, ami alátámasztja az

\section{2. ábra}

A világbajnoki cím korai megszerzésének veszélye (teljes adatbázis)

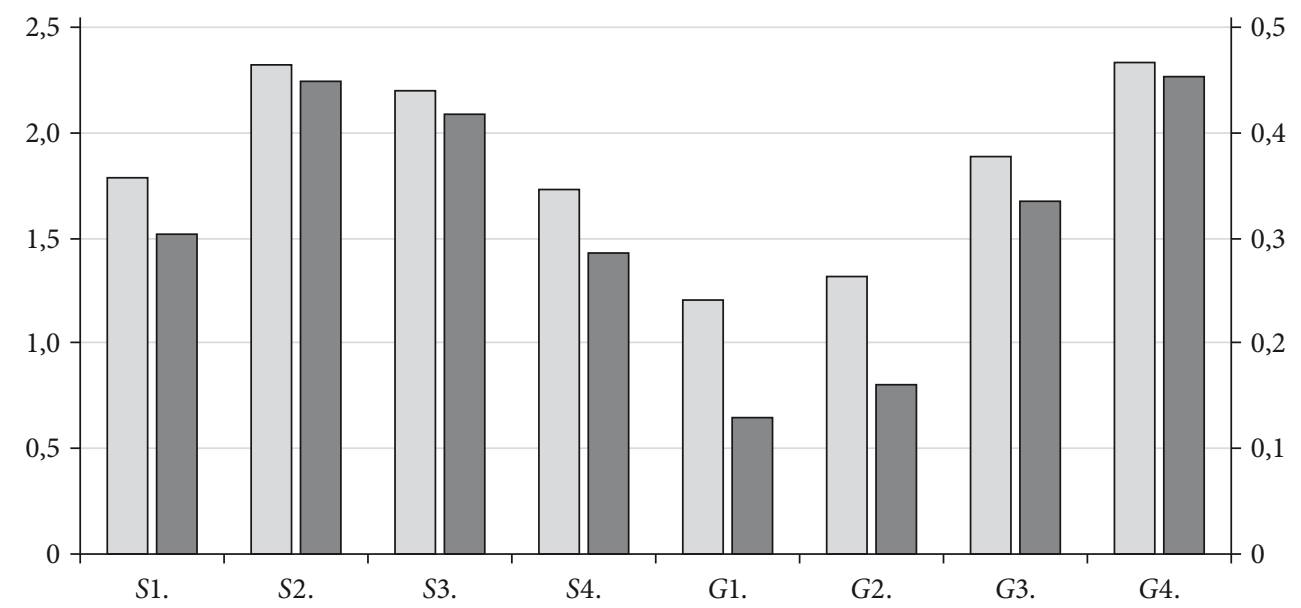

Az unalmas futamok várható száma (bal tengely)

A legalább három unalmas futam valószínűsége (jobb tengely) 
3. ábra

A világbajnoki cím korai megszerzésének veszélye (kompetitív adatbázis)

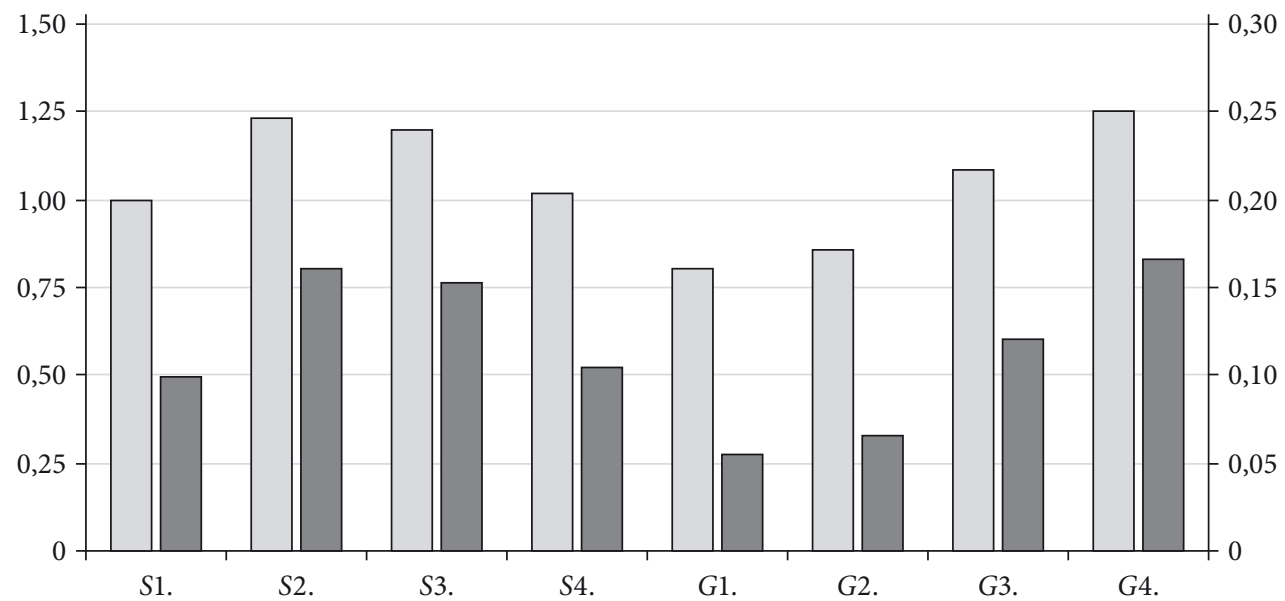

Az unalmas futamok várható száma (bal tengely)

A legalább három unalmas futam valószínűsége (jobb tengely)

alkalmazott szimulációs módszertan helyességét. Ezzel szemben a világbajnoki cím futamgyőzelem nélküli megszerzésének valószínűsége alig csökkenthető több futam rendezésével. Az ennek mérésére használt kockázatkerülö forgatókönyv viszont kétségtelenül szélsőséges feltételezéssel él, a futamok számának emelkedésével egyre valószínübbé válik, hogy a későbbi világbajnok óvatos stratégiája ellenére pusztán véletlenül nyer egy pályán.

\section{4. ábra}

Az unalmas futamok átlagos száma a futamok számának a függvényében (teljes adatbázis, eredeti forgatókönyv)

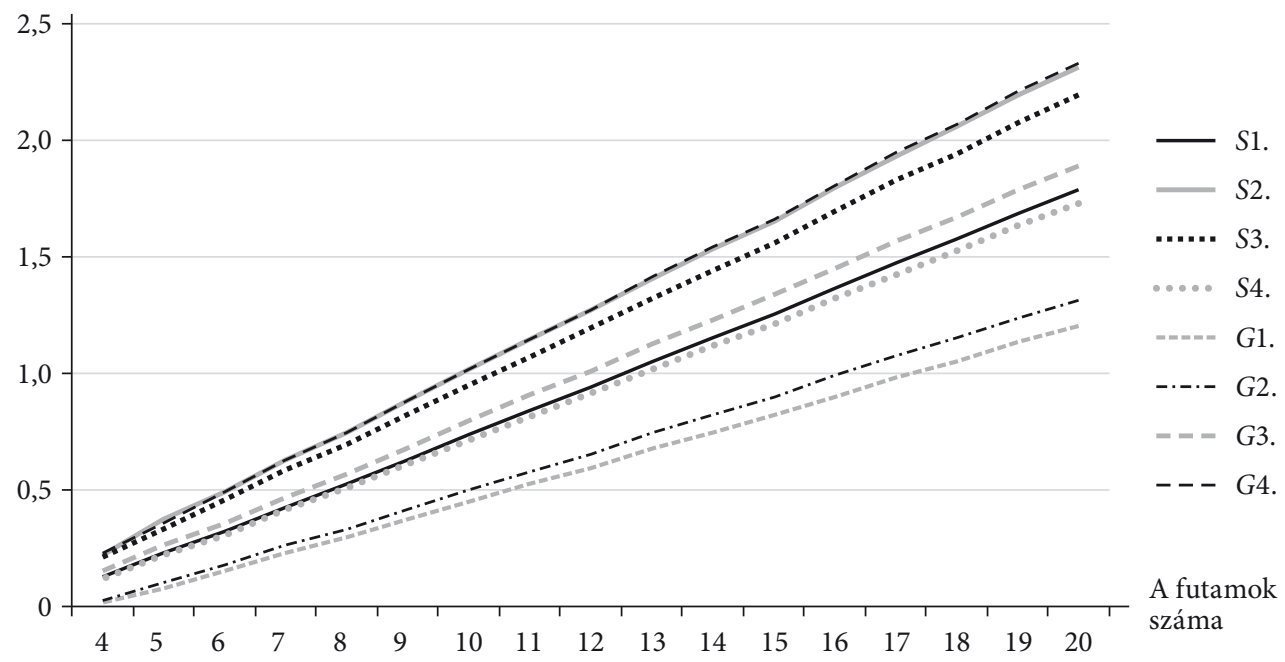




\section{5. ábra}

A világbajnoki cím futamgyőzelem nélküli megszerzésének valószínűsége a futamok számának függvényében (teljes adatbázis, kockázatkerülő forgatókönyv)

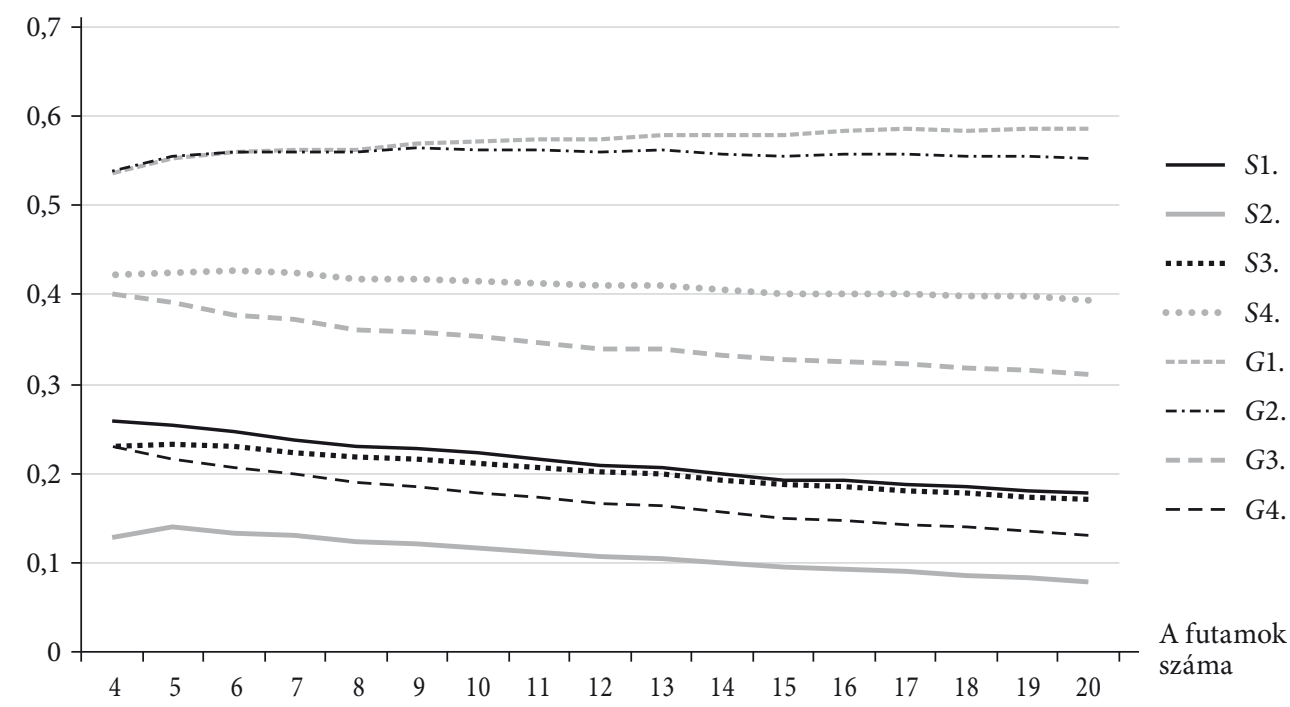

\section{Zárógondolatok}

Kutatásunk a rangsorok aggregálására széles körben használt pontozási rendszerek megértéséhez kívánt hozzájárulni, elsődlegesen sportgazdaságtani nézőpontból. Ennek megfelelően a több futamból álló bajnokságokban felmerülő két veszély közötti átváltást szerettük volna feltárni: a végső győztes kilétének korai kiderülése és a trófea egyetlen verseny megnyerése nélküli megszerzése egyaránt kedvezőtlen esetnek tekinthető. A két esemény valószínűségét a Forma-1-es autóverseny historikus adatait használó szimuláció segítségével számszerüsítettük. Eredményeink szerint a gyakorlatban használt pontozási rendszerek legalább olyan jól teljesítenek e célok tekintetében, mint az axiomatikus játékelméleti elemzés által ajánlott mértani pontozás. A jelenleg érvényes szabály megfelelö kompromisszumnak tünik a két fenyegetés kiegyensúlyozására.

A bemutatott elemzés több irányban bővíthető. A számítások robusztussága javulhat más adatforrások bevonásával. A világbajnoki cím futamgyőzelem nélküli megszerzése jelentette veszély a kockázatkerülő forgatókönyv elfogadása helyett más módon is mérhetö. A modellbe beépíthetők a pontozási rendszerek további jellemzői, a mértani pontozás nagyobb paramétere például nemcsak az első hely, hanem minden pozíció esetén ösztönözheti a kockázatvállalást. Reményeink szerint jelen tanulmány a pontozási szabályok szimulációs eszköztár segítségével végzett értékelésének első mérföldköve lehet. 


\section{Hivatkozások}

Appleton, D. R. [1995]: May the best man win? Journal of the Royal Statistical Society: Series D (The Statistician), Vol. 44. No. 4. 529-538. o. https://doi.org/10.2307/2348901.

Chebotarev, P. Yu.-Shamis, E. [1998]: Characterizations of scoring methods for preference aggregation. Annals of Operations Research, Vol. 80. 299-332. o. https://doi. org/10.1023/A:1018928301345.

CoRvalan, A. [2018]: How to rank rankings? Group performance in multiple-prize contests. Social Choice and Welfare, Vol. 51. No. 2. 361-380. o. https://doi.org/10.1007/s00355018-1120-x.

Csató LÁszló [2020a]: Optimal tournament design. Lessons from the men’s handball Champions League. Journal of Sports Economics, Vol. 21. No. 8. 848-868. o. https://doi. org/10.1177/1527002520944442.

Csató LÁszló [2020b]: Sportbajnokságok tervezése. Tanulságok a férfi kézilabda Bajnokok Ligájából. Alkalmazott Matematikai Lapok, 37. évf. 2. sz. 157-166. o. https://doi. org/10.37070/AML.2020.37.2.02.

Csató LÁszló [2021a]: A comparative study of scoring systems by simulations. arXiv: 2101.05744. https://arxiv.org/abs/2101.05744.

Csató LÁszló [2021b]: A simulation comparison of tournament designs for the World Men's Handball Championships. International Transactions in Operational Research, Vol. 28. No. 5. 2377-2401. o. https://doi.org/10.1111/itor.12691.

Csató LÁszló [2021c]: Tournament Design: How Operations Research Can Improve Sports Rules. Palgrave Pivots in Sports Economics. Palgrave Macmillan, Cham. https:/doi. org/10.1007/978-3-030-59844-0.

Csató LÁszló-Petróczy Dóra Gréta [2021]: Revenue allocation in Formula One: a pairwise comparison approach. International Journal of General Systems, Vol. 50. No. 3. 243-261. o. https://doi.org/10.1080/03081079.2020.1870224.

Dobránszky Blanka-Sziklai Balázs Róbert [2020]: Az időn múlik? Egyéni teljesítménysportok hatékonyságvizsgálata Monte-Carlo-szimuláció segítségével. Szigma, 51. évf. 4. sz.

FIA [2019]: 2019 Formula One Sporting Regulations. Március 12. https://www.fia.com/sites/ default/files/2019_sporting_regulations_-_2019-03-12.pdf.

Graves, T.-Reese, C. S.-Fitzgerald, M. [2003]: Hierarchical models for permutations: Analysis of auto racing results. Journal of the American Statistical Association, Vol. 98. No. 462. 282-291. o.

HAIGH, J. [2009]: Uses and limitations of mathematics in sport. IMA Journal of Management Mathematics, Vol. 20. No. 2. 97-108. o. https://doi.org/10.1093/imaman/dpn024.

Henderson, D. A.-Kirrane, L. J. [2018]: A comparison of truncated and time-weighted Plackett-Luce models for probabilistic forecasting of Formula One results. Bayesian Analysis, Vol. 13. No. 2. 335-358. o. https://doi.org/10.1214/17-BA1048.

Kondratev, A. Y.-Ianovski, E.-Nesterov, A. S. [2019]: How should we score athletes and candidates: geometric scoring rules. arXiv: 1907.05082. https://arxiv.org/abs/1907.05082.

Llamazares, B.-PeÑa, T. [2015]: Scoring rules and social choice properties: some characterizations. Theory and Decision, Vol. 78. No. 3. 429-450. o. https://doi.org/10.1007/ s11238-014-9429-0.

Merlin, V. [2003]: The axiomatic characterizations of majority voting and scoring rules. Mathématiques et Sciences Humaines, Vol. 41. No. 161. 87-109. o. https://doi.org/10.4000/ msh.2919. 
NitZan, S.-Rubinstein, A. [1981]: A further characterization of Borda ranking method. Public Choice, Vol. 36. No. 1. 153-158. o. https://doi.org/10.1007/BF00163778.

Petróczy Dóra Gréta [2021]: Teljesítményalapú pénzfelosztás a Forma-1-ben páros összehasonlításokkal. Szigma, 52. évf. 1. sz. 63-76. o.

Sмiтh, J. H. [1973]: Aggregation of preferences with variable electorate. Econometrica, Vol. 26. No. 1. 1027-1041. o. https://doi.org/10.2307/1914033.

Stein, W. E.-Mizzi, P. J.-Pfaffenberger, R. C. [1994]: A stochastic dominance analysis of ranked voting systems with scoring. European Journal of Operational Research, Vol. 74. No. 1. 78-85. o. https://doi.org/10.1016/0377-2217(94)90205-4.

Young, H. P. [1975]: Social choice scoring functions. SIAM Journal on Applied Mathematics, Vol. 28. No. 4. 824-838. o. https://doi.org/10.1137/0128067. 